\title{
Macroeconomic policies and economic democracy in neoliberal Brazil *
}

\author{
Daniel Bin ${ }^{* *}$
}

\begin{abstract}
The objective of this paper is to investigate some of the forms of conduct of macroeconomic policies related to a substantive concept of democracy, characterized by popular participation - direct or through representatives - in decisions that unevenly affect the material well-being of the entire Brazilian population. Special attention is given to decisions about the country's public indebtedness in the years following the launching of the Real Plan. Empirical evidences show a limited democracy, revealed by the material inequality, which in turn reproduces political inequality and restricts real freedom. This is combined with the selective bureaucratic insulation of economic policy decisions, and the parliament's failure to deal with the macroeconomic agenda. The latter is thus left to the control of the executive branch's economic apparatus, which on one hand submits itself to substantial political influence from finance and, on the other hand, restricts popular participation in decisions on both fiscal and monetary policies.
\end{abstract}

Keywords: Brazil; Economic democracy; Macroeconomic policy; Neoliberalism; Public debt.

\section{Resumo}

\section{Políticas macroeconômicas e democracia econômica no Brasil neoliberal}

O objetivo deste trabalho é investigar algumas das formas de condução de políticas macroeconômicas relacionando-as a uma concepção substantiva de democracia, caracterizada pela participação popular - direta ou via representação - em decisões que afetam de modo desigual o bem-estar material da população brasileira. Especial atenção é dada a decisões sobre o endividamento público do país ao longo dos anos que se seguiram ao lançamento do Plano Real. Evidências empíricas mostram uma democracia limitada, que se revela na desigualdade material, que por sua vez reproduz a desigualdade política e restringe a real liberdade. Adicione-se o insulamento burocrático seletivo das decisões sobre política econômica bem como a omissão do parlamento quanto à agenda macroeconômica. Esta, assim, tem seu controle exercido pelo aparato econômico do poder executivo, que, por um lado, submete-se à significativa influência da finança e, por outro, limita a participação popular sobre as decisões de políticas monetária e fiscal.

Palavras-chave: Brasil; Democracia econômica; Neoliberalismo; Política macroeconômica; Dívida pública.

JEL D72, E62, E69, H63, H69.

*Article received on December 10, 2014 and accepted on June 16, 2015. An earlier version was presented at the 108th American Sociological Association Annual Meeting, New York, Aug. 2013. The author is grateful for the comments of the two anonymous reviewers of Economia e Sociedade, who are exempt from any of the paper's remaining deficiencies. The work was supported by National Council for Scientific and Technological Development (CNPq), Brazil (Grant number 471535/2011-7).

${ }^{* *}$ Professor of Public Policy at the University of Brasilia ( $\left.\underline{\mathrm{UnB}}\right)$, Brasilia, DF, Brazil. E-mail: daniel.bin@uwalumni.com. 


\section{Introduction}

The transition from a dictatorship to a formally democratic regime was one of the most outstanding phenomena in recent Brazilian political history. After more than twenty years of military dictatorship (1964-1985), the most important institutions of liberal democracy were re-established in the country. In addition to the formally independent republican powers - such as parliament no longer being under the threat of the interventions made by the executive branch during the military regime - the country now has free and periodic universal elections, a variety of political parties and formal individual liberties. A new Constitution was also enacted to substitute the one dictated by the military dictatorship. This new Constitution has established other political rights, highlighted by the opening of routes for a certain degree of participation by society in state decisions.

The 1988 Constitution also established some social rights to institutionalize policies associated to the so-called welfare state. Although the measures have been effectively weaker than those found in the Northern hemisphere, the route to the provision of broad welfare measures was opened. The universalization of healthcare, the expansion in the number of beneficiaries and the minimal benefits for social security and social assistance, as well as universal access to public education were rights attained by society at the time of redemocratization, inasmuch as the new Constitution earmarked portions of tax revenues to fund them. This limited the chance for social policies to depend on the good will of whatever government happens to be in power, which pointed to a distancing of the Brazilian state from its history of clientelism.

On the other hand, at a time in which formal institutions of liberal democracy and welfare policies were structured, in the mid-1990s this trend suffered an inflection with the arrival of the neoliberal wave that had irradiated from the North in the two previous decades. This imposed a new politicaleconomic reality on Brazilian society that would setback the recently inaugurated democratizing trend, especially in relation to the economy. At the same time that the liberal democratic institutions were strengthened, under a concept of true democracy - which would include economic equality and strong popular participation in economic decisions - the reality in construction was that of a considerably limited democracy.

Particularly with the implementation of the Real Plan, which was launched in mid-1994 and was a mark of the neoliberal wave, the distance began to grow between what would be an economic democracy and the liberal democracy that had been staging a comeback since the mid-1980s. The Real Plan, by eliminating the inflation that until then was inculcated in social representations as the largest of all the socio-economic problems, was crowned as one of the 
greatest conquests of Brazilian society in the 1990s. This situation guaranteed that inflation control would be a priority, and thus any economic policy, and its forms of decision making, appeared to be self-justifiable as long as they considered monetary stability. Without wanting to insinuate that this antiinflationary fundamentalism makes the state today less democratic than it had been throughout its historic mutual reproduction with capital, the antidemocratic character now assumes a version sponsored by finance. As Amin (2008, p. 72) affirms, "the new plutocratic capitalism of the financialized oligopolies is the enemy of democracy, draining it of its substantive content."

In this context, the objective of this paper is to investigate some of the forms of conduct of macroeconomic policies related to a concept of democracy that is characterized by popular participation - direct or through representatives - in decisions that unevenly affect the material well-being of the entire Brazilian population. Among these policies, special attention is given to public debt. This is based on the hypothesis that the decision-making processes related to the public debt are based on a logic that causes Brazilian capitalist democracy to reproduce an antithesis between capitalism and democracy - the latter cannot exist along with the former. In this light, in the following section I present a conceptualization of democracy considering structural limitations imposed on it by capitalism. In the third section, I address the processes by which economic policies are excluded from the broader political debate to avoid questioning about the standards of capital accumulation, currently based on a financial logic. I will then discuss the power concentrated in the state's economic apparatus, which, at the same time that it is not submitted to parliamentary or social controls, shares ideas and practices with the financial fraction of capital. Before concluding, I discuss the concept of performativity of economics to cast light on the opportunities that the financial classes have to influence decisions concerning monetary policy that can be favorable to them. I conclude by arguing that the route to democratic socialism passes through democratization of economic decisions.

\section{Capitalism or democracy}

The idea that capitalism and democracy naturally imply the mutual presence of one another has become hegemonic. The experience of so-called real socialism, by combining non-private ownership of the means of production and centralized economic coordination with totalitarian forms of government, played a fundamental role in the consolidation of this belief. Its comparison to the group of countries in which the combination of private property and economic coordination via markets, supported by liberal democratic political systems, helped to construct a clear opposition: capitalism and democracy on one hand; socialism and totalitarianism on the other. This was so much the case that the 
immediate reaction from Western commentators to the collapse of the Soviet regime was to declare the permanent triumph of capitalism and liberal democracy (Hobsbawm, 1996).

This created a central problem for socialism in the moments following the Soviet collapse: to show that societies could develop some form of selfgovernment that combines social equality and political liberty (Weffort, 1992). Not even the fact that this did not occur as a continuation of that phenomenon to defeat an empire does not imply that better institutions will be established, as the post-Soviet experience in Russia shows (Block; Evans, 2005; Evans, 2008), which, moreover, like the majority of post-communist societies, upon throwing themselves directly into democracy and capitalism, experienced economic failure as a result (Žižek, 2008) - was enough to obfuscate the idea that capitalism was definitively a democratic economic system while socialism was not. From this, an ideology also resulted in a way that has proved to be sufficiently functional for supporting the maintenance of the political legitimacy that capital needs to reproduce itself with relative stability.

This ideology, however, can be refuted by looking at some brief historic examples, when capital was able to develop without liberal democracy. This is demonstrated in Brazil by the Getúlio Vargas dictatorship (1937-1945) and the military dictatorship (1964-1985), which were both coincidental with strong economic growth. It is not inappropriate to recall the alliance between the large capitalist powers and Stalin's Soviet Union whose Red Army was responsible for the victory over Hitler's Germany (Hobsbawm, 1996). Nevertheless, a market economy can only develop under certain democratic conditions, and social structural conditions for a stable democracy can only be established under a developed market economy (Offe, [1991] 2004). In the long term, capital requires that the political system be organized under a bourgeois type of democracy, because a state apparatus that is too strong can create other types of threats to capital. Moreover, it is essential for capital to be able to free itself from governments that are incapable of responding to the concerns of its hegemonic class fraction.

According to Cohen and Rogers (1983), a capitalist democracy, just as it is not solely capitalist, is not solely democratic, because political rights - those of expression, association, voting-to which citizens have access are more formal and procedural than substantive. For example, they do not consider in their form of application inequalities in the distribution of resources that decisively affect the exercise of political rights and limit the power of expression. As Bourdieu (2001) teaches, all political agents do not have the same level of access to the instruments needed to produce their own opinion, particularly cultural "capital." Thus, for Bourdieu, the vote does not establish the condition for the true universal 
suffrage as it was intended to, unless conditions for accessing the universal become truly universalized.

On the other hand, Cohen and Rogers (1983) also argue that capitalist democracy differs from pure capitalism, because the same political rights mentioned earlier, and a series of actions in the political arena, allow workers to interfere in state policies, and in this way to influence the behavior of capital. These rights, Cohen and Rogers add, even if they have no guarantees, make capitalist democracy more favorable to the material gains of workers than other capitalist regimes, such as fascism or bureaucratic authoritarianism. Together with the uncertainty surrounding the results of a possible revolution, which in itself discourages such a movement, the possibility for immediate and therefore more concrete gains or compensation leads to consent by the part of the subaltern classes to maintain their demands within a safe level for capital (Cohen; Rogers, 1983; Przeworski, 1985). This is how the class commitment is constructed between the capital and labor that is required for the maintenance of internal peace and tranquility (Harvey, 2005).

It happens that this form of political organization is in itself antidemocratic, for at least two reasons. The first is revealed in the contradiction inscribed in the very ideal of liberty as it is understood by the liberals, who recognize the individual as the fundamental analytical category. According to Offe (2001), the concept of liberty follows an ambivalent logic, to the point that the distinction between "my" liberty and "your" liberty is capable of causing the latter to appear to "me" as the liberty of one who does not truly deserve it. Liberty does not exist for an individual who is compelled to submit oneself to the other, as is the case of those who own only their own labor force in relation to owners of the means of production. Rousseau ([1757] 2005, p. 127) once affirmed that to have civil liberty it is necessary that "no citizen be sufficiently opulent to be able to buy another and that no one is so poor that he finds himself forced to sell himself."

The second motive - stemming from the above description - that makes genuine democracy incompatible with capitalism resides in the fact that capitalism is structurally characterized by economic inequality, which in turn implies important restrictions to the political capacity of individuals, classes, or class fractions to influence their destinies. Capitalism limits democracy, for example, in the fact that private property impedes collective access to decisions about important domains of economic activity (Levine, 1995; Wright, 2006). Thus, a truly democratic order cannot evolve under free and equal conditions if some of its members monopolize the decisions about the allocation of the surplus of social production (Cohen; Rogers, 1983). The concentration of economic power subverts democratic principles by doting the property owning classes with 
an disproportional capacity to influence political results through financing of politicians and political organizations, control over the major media, hiring bureaucrats and politicians when they leave government and lobbying government officials - which, nevertheless, will have broad collective effects (Wright, 1994; 2005).

In this situation, public debt, for example, by involving economic inequality between social actors, and by counting on the support of state intermediation, joins other institutions of capitalism to reveal its character antithetical to democracy. Particularly in the periphery of the world economy, financial organizations are able to exercise commanding pressure in order to obtain monetary policies favorable to greater financial liberalization (Chesnais, 1998) without significant debate within society as a whole. In the Brazilian case, the concentration of financial capital in just a few organizations has generated their strong interest in macroeconomic policies, resulting in a situation in which a small number of social actors have much more influence over government decisions in this realm than other social forces (Minella, 2007).

Economic policies in general, and public debt in particular, thus require an institutional apparatus guided by a logic of action as if there effectively were no alternative, guided by a supposed market whose demands are all self-justified. In this way, considering what we have seen up until now, we can suppose that the elaboration and execution of such policies are based on the exclusion of many points of view and by the influence of a limited number of actors. This, as well as the factor of inequality, steers our attention to the study of how political practice in a supposedly democratic environment can be profoundly antidemocratic. This factor is especially important for the following discussion, which investigates precisely how certain issues - economic policies - can be systematically excluded from any truly democratic political debate.

\section{Depolitization of economic policy}

In the context of economic liberalization, finance became the hegemonic fraction of capital, first at the international level and later in Brazil. This took place with the state performing the role as the central institution in the realization of reform measures. This phenomenon signified a deepening of the antidemocratic character of capitalism by expanding the rate of labor exploitation through increased taxes and reduced wages - and reducing the provision of public goods on which the poorest social fractions depend (Bin, 2015). Procedurally antidemocratic measures were also necessary to implement the reforms that placed finance in a hegemonic position. As Przeworski (1992, p. 56) summarized, "since the neoliberal 'cure' is a painful one, with significant social costs, reforms 
tend to be initiated from above and launched by surprise, independently of public opinion and without the participation of organized political forces."

In the previous section we saw the substantive aspect of economic inequality as antithetical of effective democracy. We also saw that, although capitalism and democracy are theoretical constructs that deny each other, empirically, capitalist democracies are organized in gradations of capitalism and democracy. In them, economic and political power are not totally centralized. Nevertheless, the economic inequality must be sufficient to include the few and exclude the majority from decision-making processes that affect the entire society. It stems from this that power, contrary to the idea that Foucault (1979) had about its microphysical character, is not a manifestation that is impossible to locate. It is the capitalists - and they are relatively few - who command production and investment and for this reason exercise influence on the economic policies of the state, which have broad consequences for the whole of society (Bowles; Gintis, 1986).

Nevertheless, there are no guarantees that economic inequality would be enough to maintain the system that enables such inequality to reproduce. Given that capitalism depends on liberal democracy, movements towards a democratic configuration that exceeds these limits can make politics less safe for capital. The greater involvement of society in decisions that are of its concern tends to influence political decisions in a way that expands the space for new interested actors to influence policy, thus imposing restrictions on the previously hitherto present interests. If this process is effective, we could then envision a trend toward a more egalitarian allocation of social wealth to the degree that more actors would share in the decisions. It is not necessary to say that this movement would meet resistance from those who have something to lose from it, because, as Przeworski (1992, p. 53) recalls, "democracy inevitably threatens "property rights'."

We reach the point in which the other democratic requirement that I will highlight - the first one is that of economic equality - proves to be just as incompatible with capitalism. This requirement involves egalitarian participation - directly or by means of representatives - in the decisions that affect the entire society, which, in an effectively democratic reality, would be largely encouraged. The incompatibility between capitalism and democracy, according to this idea, stems from the fact that "participatory models of the organization of state productive activities that aim at increasing administrative responsiveness are ... inadequate ... because they tend to crystallize conflict and protest and can thus easily become subversive of the balance between the state and the accumulation process" (Offe, 1975, p. 143, emphasis in original). Concerning the productive activity of the state, Offe distinguishes the activity of allocation, which refers to the power to redistribute resources via government policies. An example is the 
tax system; another can be the conduct of other economic policies, such as monetary policy.

While Offe emphasizes the incompatibility between the state's productive activity and participatory models, this is no less true for the activity of allocation. In addition to the democratic limits to the participation of the subaltern classes imposed by the socioeconomic structure, institutions are configured to limit the access of society as a whole to the political debate. If class exploitation requires a certain political configuration to be maintained, and if this configuration tends towards the radicalization of democratic practice, inequality - which implies a class advantage - is itself threatened. It is for this reason that institutions tend to restrict the exercise of democratic policies in the activities of allocation as well as production. We live under that which Swanson (2008) calls the depolitization of the economy, which is manifest by at least two related means: the conceptual naturalization of economic practices and the limited political control on them.

In this context, we have the establishment of absolute truths. Economic issues are presented to society as if there were no alternatives, since they are insulated from political influences - but not from all influences - and made legitimate by one form of technical knowledge (I will discuss this in the fifth section). Here we also see that the state, by detaining the legitimacy to issue discourses about "truths," has not weakened as certain theories or common sense opinions would have us believe. It happens that the state has the means to impose and inculcate long-lasting principles of vision and division according to its own structures and, as such, is the very location of the concentration and exercise of symbolic power (Bourdieu, [1994] 2011). Thus, if the level of democratization of a society refers to the expansion of the decisions subject to democratic control in addition to the extension of political equality (Wright, 1994), the depolitization of the economy lowers this level, because the consequences of economic decisions are experienced by all of society, although unevenly across classes and their fractions.

The exclusion of themes from the political debate is part of the arsenal of institutional arrangements developed within the state, considering its primordial function to maintain the mode of production and specific forms of accumulation. According to Offe (1974, p. 36), the capitalist state is governed in such a way that policies are generated selectively, in a process of choice configured in "institutionalized exclusion rules." These rules of selection compose the internal structure of the state apparatus, and define the class character of the state in two ways. In one, selectivity operates through the positive action of the state, which formulates policies that coincide with the collective interests of capital, that is, those which do not consider the interests of particular fractions capable of 
compromising the accumulation of capital. In the other form of selectivity, the state acts negatively, preventing both the development of conflicts and the organization of anti-capitalist interests.

Given that the commitment of the state is to the collective interests of capital, and that, nevertheless, the process of accumulation takes place under the hegemony of one of the fractions of the capitalist class, the selectivities referred to by Offe are also based on this restriction. That is, the selectivities - positive and negative - of policies can refer at some time to the interests of the hegemonic fraction. The formulation of fiscal and monetary policies and those concerning public debt in Brazil corroborate Offe's thesis, in particular the negative form of selectivity. These issues, which are of greatest interest to the financial fraction of capital, are not submitted to any public debate that is potentially anti-finance. Protected from broad social scrutiny, they are less likely to be the objects of social conflict.

One way to synthesize the mechanisms of selection to which Offe refers is the institutional configuration that takes place in the management of macroeconomic policy. One of the marks of these policies is the distinction between the economy and politics, which has repercussions on the ideology that fiscal and monetary policies are strictly economic issues and for this reason must be based on purely technical decisions. In these issues, the discourse is that of liberal social theory, which is divided into liberal political theory that does not address the economy, and liberal economic theory that ignores politics (Bowles; Gintis, 1986). An example of this was given by the Brazilian minister of finance in early 2010 - a presidential election year - by proposing what he called "a sustainability pact." He affirmed that it was necessary to "shield the Brazilian economy from the elections." For the government, the minister said, this meant a "commitment to maintain solidity (fiscal and monetary) and the same responsible conduct as in the non-electoral period;" for business this meant "maintaining normal performance, not accepting provocations, not believing in distortions," and "demanding a commitment to the maintenance of solid foundations and successful growth policies ${ }^{1}$."

The idea of democracy as state power subordinated to social power, and of the latter as a limiter of the former (Wright, 2005), to which Gramsci ([1932] 2004 , p. 50) referred to as "government with the consent of the governed," has thus not found significant empirical expression in the conduct of economic policies. This is because, as Harvey (2005) indicates, neoliberal theoreticians are

(1) Presentation of the Brazilian minister of Finance entitled "Brasil: preparado para crescer". LIDE Conference, São Paulo, Feb. 2, 2010. Available at: http://www.fazenda.gov.br/divulgacao/ apresentacoes/2010/p020210-pdf21/view. Accessed August 8, 2015, emphases in original. 
deeply suspect towards democracy, because to govern under the rule of the majority is a threat to individual rights and constitutional liberties. The neoliberal solutions involve a preference for governance exercised by specialists and elites, by decisions taken in the realm of the executive and judiciary branches instead of those democratically produced by parliamentary means and finally, by insulating key institutions - the central bank being one of them - from democratic pressure. This involves what Jessop (2010) calls the fetishism of the separation between the economic and political moments of capital. Moreover, it is in this separation, and in the idea of a citizenship separated from its social interest and from the struggle around the accumulation of capital that the fetishism of the state is manifest (Costilla, 2000). For this reason, Wood (1981) is correct in saying that perhaps there is no greater obstacle to a socialist project than the separation between the economic and political struggles.

\section{Selective bureaucratic insulation}

One of the phenomena that makes macroeconomic policies an expression relevant to the contraction of democracy is the reduction of spaces for debate and deliberation. Beyond the objections about the effectively democratic character of the parliament in a capitalist state, what is important is that this democratic character can be weakened even more when spaces of action are hegemonically occupied by the executive branch, as the political parties do in the face of the state bureaucracy in a movement caused by the central role of the economic apparatus of the state (Poulantzas, [1978] 2000). In the Brazilian case, these movements occurred, for example, during industrialization (Ianni, [1989] 2004) and more recently, with the measures for fiscal and monetary stabilization (Diniz, 2004).

The phenomenon of the preponderance of the executive is not particular to peripheral states; the United States, France, Great Britain and the former West Germany are examples where this has taken place at the center of global capitalism (Arendt, [1972] 2006; Poulantzas, [1978] 2000; Wright Mills, [1956] 1981). In the majority of countries, it is the executive branch that practically controls investment and currency policies, interest rates, loans, social spending, taxes, fiscal incentives, international and domestic trade policies and public debt (Costilla, 2000). The dominance of the executive branch in the most important decisions causes, in the case of Brazil, what Saes (2001) calls a limited democracy, leading to the emergence of a civil authoritarianism whose strongest evidence is the removal of the power to legislate from parliament through the use of the provisional decree ${ }^{2}$.

(2) In Portuguese the term used is medida provisória, which is a decree issued by the president of the Republic that has the strength of a law until it is reviewed by the legislature. 
This contraction of democracy has important material effects for all of society. This is because "the inability of democratic bodies to control the movement of capital undermines the ability of democracy to set collective priorities over the use of social resources" (Wright, 2005, p. 199). Investment is a central decision for a broad set of social objectives (Wright, 1998). Being the only guarantee of the future for a society, if it is not subject to social deliberation, democracy is fundamentally restricted and incomplete (Cohen; Rogers, 1983).

An example of the restriction to popular participation in decisions about distribution of resources of the Brazilian state took place in May 2001 when the Chamber of Deputies created the Participative Legislative Committee to facilitate popular participation in "suggestions for legislative initiatives presented by associations and professional entities, unions and organized civil society entities ${ }^{3}$." Going against this measure, by disciplining the deliberation of issues in the congressional joint budget committee, the Congress prohibited this "participative" commission from presenting amendments to the budget bill proposed by the executive branch ${ }^{4}$. Another example took place through the fiscal responsibility law, which called for the creation of a "fiscal management council, formed by representatives of all branches and spheres of government, the attorney general's office and technical entities representative of society" to "permanently accompany and evaluate the policies and operationality of fiscal management ${ }^{5}$." In late 2000, the year the fiscal responsibility law was signed, the president of the Republic presented a proposed law for the creation of this council, which is still being deliberated by the Chamber of Deputies while the council has not yet been created ${ }^{6}$.

Another manifestation of the insulation of economic decisions can be seen in the highest regulatory institution of the Brazilian financial system, the National Monetary Council (CMN in Portuguese). Created in 1964 under the military dictatorship, one of the goals of the $\mathrm{CMN}$ is to "coordinate monetary, credit, budget and fiscal policies, and those related to the domestic and foreign

(3) Chamber of Deputies resolution n. 21, May 30, 2001. Available at: http://www2.camara.leg.br/legin/int/rescad/2001/resolucaodacamaradosdeputados-21-30-maio-2001-319754publicacaooriginal-1-pl.html. Accessed: Aug. 8, 2015.

(4) National Congress resolution n. 1, Dec. 22, 2006 (articles 43 and 44). Available at: http://www2.camara.leg.br/legin/fed/rescon/2006/resolucao-1-22-dezembro-2006-548706-normaatualizadapl.html. Accessed: Aug. 8, 2015.

(5) Complementary law n. 101, May 4, 2000 (article 67). Available at: http://www.planalto.gov.br/ccivil_03/leis/LCP/Lcp101.htm. Accessed: Aug. 8, 2015, emphasis added.

(6) President's message to National Congress n. 1,658, Nov. 7, 2000. Available at: http://imagem.camara.gov.br/Imagem/d/pdf/DCD11NOV2000.pdf. Accessed: Aug. 8, 2015. 
public debt ${ }^{7}$." One can see that its role is not modest, considering what its decisions can represent for the economy and for the living conditions of society in general. In this sense, it would be reasonable if the $\mathrm{CMN}$ included representation from various social segments. In addition, it would also be reasonable if, with the end of the military dictatorship, the council had greater possibilities for social participation.

Nevertheless, the CMN is a clear example of how a state institution can become even less representative of the various segments of Brazilian society. Its evolution took place in such a way that, created and expanded under the military dictatorship, it came to initiate a process of greater insulation precisely under the first government elected by direct vote since the council's creation - that of President Fernando Collor de Mello (1990-1992). This movement was radicalized with the release of the Real Plan (1994), when the council was reduced from twenty to only three members. Since then, the CMN has been composed of the minister of finance, the minister of planning, budget and management and the governor of the Brazilian Central Bank (BCB), i.e., a composition that has only economic policy-makers within it. The representation of workers, which was only established in 1987 and composed of just one member, was also ended in 1994.

The importance of the CMN to my argument resides in the fact that it is the board responsible for setting goals for inflation within the current monetary policy regime, which is based on the management of the basic interest rate. This rate has immediate impact on all economic activity, and is the primary criterion for investment decisions. In this way, one activity tends to be privileged in detriment to another, depending on the expected rate of return of each. For example, if government bonds pay higher rates than the growth rate of the real economy, investments in the latter would tend to be sacrificed in favor of loans to the government. As Figure 1 demonstrates, this is precisely what has happened since the first neoliberal movements, inverting the trend observed until the late 1980s. One can see that gross fixed capital formation (GFCF), which represents total investment in the means of production, tends to grow in contexts of lower real interest rates and to decrease when interest rates are higher.

(7) Law n. 4,595, Dec. 31, 1964 (article 3, item VII). Available at: http://www.planalto.gov.br/ccivil_03/leis/L4595.htm. Accessed: Aug. 8, 2015. 
Figure 1

Interest rates, economic growth and fixed investment, 1970 to 2013

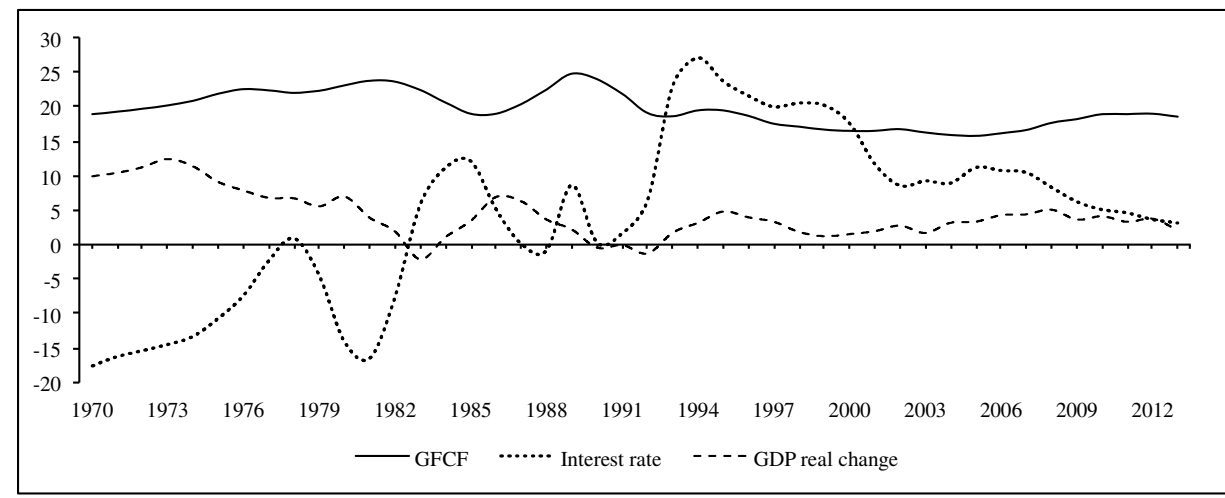

Notes: i) percent scale; ii) three-year moving averages; iii) GFCF as a percentage of GDP; iv) Over/Selic interest rate in ex-post real terms.

Source: Author's calculations from the Instituto de Pesquisa Econômica Aplicada (Ipea).

Regarding this point, differently from analyses that conclude that the Brazilian state has an accentuated degree of bureaucratic insulation, I understand that this is a selective insulation. That is, the state apparatus does not isolate itself from the concerns of all of society, but from the concerns of a part of it, the latter being the majority. The state economic apparatus maintains important connections with certain portions - classes - and is subject to their influences and attends their concerns and demands (Bin, 2014). These portions include capitalists in general and, in particular ascendance, finance. Government is not insulated from finance capital insofar as there exists a sharing of ideologies among financial interests and the members of the formulating agencies or executors of economic policies. In this way, the capitalist state comes far from encompassing an element that Cohen and Rogers (1983) define as one of the requirements of an effectively democratic society, which is the guarantee that all those interested in the consequences of a decision can participate in it with a chance to influence it.

This is also the case of another decision making body that is highly important to the Brazilian economy, the Monetary Policy Committee (Copom in Portuguese) of the Brazilian Central Bank, which is formed by members of the central bank's board of governors. Created in 1996, Copom is responsible for implementing monetary policy, and for determining the basic interest rate of the Brazilian economy - known as the Selic rate - which is a reference for all other short and medium term rates practiced in the country. In this way, its decisions affect all economic activity, which is the variable that is managed in order to contain inflation. In addition to the impacts on the levels of economic activity and 
on prices, it has immediate effects on the cost of the public debt provoked by variations in the basic rates and others that follow it.

It is not difficult to recognize the scope of the immediate reflections of Copom's decisions on public finance, and consequently for various fractions of social classes. It is possible to estimate, at least roughly, to what degree decisions about spending of the state budget are concentrated in a few hands; decisions that do not need to be submitted to any substantive parliamentary and social controls. At each rate-setting meeting of Copom, its current nine members decide with considerable autonomy from society as a whole about an important portion of interest on the public debt that will be steered by the state to the financial classes.

After the implementation of the Real Plan, there was a shift in power with a considerable degree of discretion passed to the monetary authority to make decisions about a significant portion of state expenditures. For this reason, alongside interest on public debt tied to the Selic rate, in Figure 2 I placed two types of spending with regard to which the government has a high degree of discretion. One of them is investment, which during most of the period under analysis was systematically and largely exceeded by accrued real interest on public debt due to the restrictive monetary policy. The other type of expenditure that has a high degree of discretion involves spending on social policies, such as education, culture, healthcare and sanitation, including sewerage and water supply.

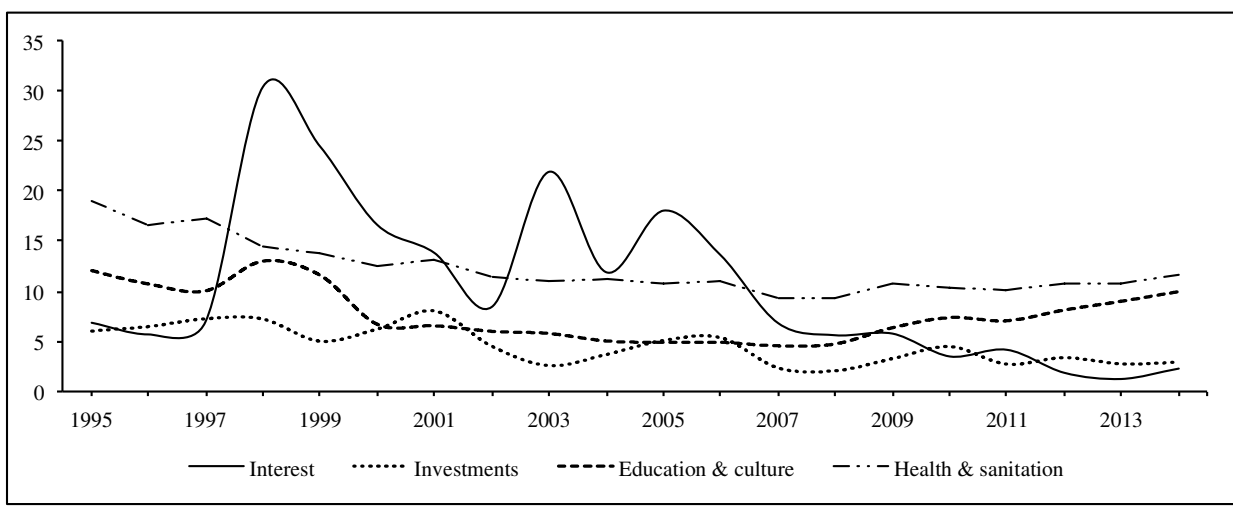

Notes: i) percent scale; ii) in relation to federal tax revenues, except social security contributions; iii) interest in real terms.

Sources: Author's calculations from Ipea, BCB, and Secretaria do Tesouro Nacional.

The numbers in Figure 2 indicate that between 1998 - this was the year of the Russian monetary crisis, followed by currency fluctuation and the adoption 
of inflation targeting in Brazil in 1999 - and 2006, the accrued real interest linked only to that portion of the public debt tied to the Selic rate was equivalent to an annual average of about 17.7 percent of federal tax revenue. At the same time, investment spending represented 5.3 percent, spending on education and culture 7.2 percent, and on healthcare and sanitation an average of 12.1 percent in relation to federal tax revenues. Only since 2007, with the beginning of the global crisis, has real interest fallen to levels below spending on some of the other items. During 2007-2014, the Selic-tied accrued interest fell to 3.9 percent, still above spending on investment, which amounted to 3 percent of federal tax revenues, but below spending on education and culture, which was 7.2 percent, and on healthcare and sanitation, which averaged 10.4 percent in relation to federal tax revenues.

It is fitting to briefly describe the legal apparatus that protects the interests of finance by keeping them practically immune from the political debate. First, it is the Brazilian Constitution that presents mechanisms that are sufficiently vague so that decisions about the public debate remain concentrated in the hands of the executive branch. For instance, it rules that "the president of the Republic shall have the exclusive power to ... submit to the National Congress the pluriannual plan, the bill of budgetary directives and the budget proposals" of the Union; the Constitution also determines that "the amendments to the proposed annual budget legslation or to the bills which modify it may only be approved if ... they specify the necessary funds, allowing only those resulting from the annulment of expenses, excluding those which apply to: a) allocations for personnel and related fees; b) debt servicing; c) constitutional tax transfers to the states, municipalities and the Federal District ${ }^{8}$."

Combining the two points above, the Constitution enforces that the proposal for interest and amortization of the public debt that is found in the respective proposed budget law sent by the executive to the parliament cannot be modified by the latter for other expenses that it deems necessary. A very telling description of how public debt is dealt with in the budget debate by the Brazilian parliament was expressed in this way by one of its members:

In the 3 years that I participated in the [Plans, Public Budget and Supervision Committee (CMO in Portuguese)], as coordinator of the caucus, as a member, each time in which the debt was to be discussed, no one discussed it: "Ah!, this is not the place for that." What do you mean?! If we cannot discuss it in the CMO, at the time in which the budget is voted, when will we discuss it? ... How many times, I am a witness, have I seen

(8) Brazilian Constitution, Oct. 5, 1988 (article 84, item XXIII, and article 166, paragraph 3, item II). Available at: http://www.planalto.gov.br/ccivil_03/constituicao/constituicao.htm. Accessed: Aug. 8, 2015, emphasis added. 
a congressperson ... who wanted to manifest this to the minister [of Planning] ... and to the president of the Central Bank, and [the answer was]: "It's not here, no, we cannot discuss that; this is not the issue." But what is the issue?! We're discussing the budget and we cannot discuss the debt? ${ }^{9}$

Thus, the Brazilian case is one more to confirm the old Weberian thesis that a bureaucratic government, by its very nature, is a government that avoids publicity, given that bureaucracy hides its knowledge and its activity as much as it can in the face of criticism (Weber, [1922] 1964).

I previously mentioned that the dominance of the executive branch in the most important decisions makes Brazil that which Saes (2001) calls a limited democracy, from which emerges a civil authoritarianism. The evidence of this is the parliament's limited power to legislate due the capacity of the president of the republic to issue provisional decrees with immediate force of law. Some commentators even see this capacity as a preservation of the power to issue decree-laws that presidents had during the military dictatorship of 1964-85 (Figueiredo; Limongi, 2000). It must be added that this current presidential power was granted by the legislature in the Constitution of 1988 and has been maintained since then ${ }^{10}$. It was precisely the provisional decree that was used to enact the law that currently authorizes the executive to issue government bonds. In November 1994, the president of the Republic issued a provisional decree that would be re-issued more than 80 times over six years until it was turned into the law that until today governs the federal public debt bonds ${ }^{11}$. That is, the law that authorizes the executive branch to issue government bonds was not born from parliamentary discussion, and much less from any broader social debate.

This law does not make any mention of the issue of interest, limiting itself to themes such as purposes, denominations, methods of issue, registration and other secondary characteristics of the bonds. It vaguely defines that it is to the "executive branch [to determine] the general and specific characteristics of the public debt bonds." In recent years, by means of decrees, the executive has defined characteristics such as the maturity, yield, interest rate and form of actualization, among others ${ }^{12}$. Nevertheless, for some types of bonds the law

(9) Chamber of Deputies' meeting transcript n. 1233/09, Aug. 19, 2009. Available at: http://www2.camara.leg.br/atividade-legislativa/comissoes/comissoes-temporarias/parlamentar-de-inquerito/ 53a-legislatura-encerradas/cpidivi/notas-taquigraficas. Accessed: Aug. 8, 2015.

(10) I owe this observation to one of the Economia e Sociedade's referees.

(11) Provisional decree n. 470, Apr. 11, 1994. Available at: http://www.planalto. gov.br/ccivil_03/mpv/Antigas/470.htm. Accessed: Jan. 7, 2013; Law n. 10,179, Feb. 6, 2001. Available at: http://www.planalto.gov.br/ccivil_03/LEIS/LEIS_2001/L10179.htm. Accessed: Aug. 8, 2015.

(12) The issue is currently regulated by presidential decree n. 3,859, Jul. 4, 2001. Available at: http://www.planalto.gov.br/ccivil_03/decreto/2001/D3859.htm. Accessed: Aug. 8, 2015. 
stipulates that the minister of finance has the discretion to define their characteristics, including interest rates. This has concentrated a relatively important portion of power to determine the destination of the wealth to the financial sector that is handled through public debt. Following, in Figure 3, is a synthesis of this concentration of power.

Figure 3

Concentration of decision making about securitized debt, 2000 to 2014

\begin{tabular}{l|c|c|c|c|c|c|c|c|c|c|c|c|c|c|c}
\hline Year & 2000 & 2001 & 2002 & 2003 & 2004 & 2005 & 2006 & 2007 & 2008 & 2009 & 2010 & 2011 & 2012 & 2013 & 2014 \\
\hline $\begin{array}{l}\text { Selic rate (defined by the } \\
\text { BCB's Copom) }\end{array}$ & 21.9 & 24.7 & 25.2 & 26.1 & 23.6 & 23.5 & 17.4 & 15.4 & 14.9 & 15.4 & 13.8 & 13.2 & 9.7 & 8.2 & 8.3 \\
\hline $\begin{array}{l}\text { Fixed rate (understood to be } \\
\text { defined by the MF) }\end{array}$ & 6.3 & 3.7 & 0.9 & 5.4 & 8.4 & 12.7 & 16.7 & 17.2 & 13.4 & 14.6 & 16.1 & 16.5 & 18.0 & 18.1 & 18.6 \\
\hline $\begin{array}{l}\text { Price indices plus interest rates } \\
\text { to be defined by the MF }\end{array}$ & 0.6 & 1.8 & 3.8 & 4.6 & 5.3 & 6.4 & 9.8 & 11.6 & 11.8 & 12.0 & 11.6 & 12.5 & 15.2 & 14.8 & 15.5 \\
\hline $\begin{array}{l}\text { Various (defined by decree or } \\
\text { by the MF) }\end{array}$ & 4.8 & 6.4 & 6.1 & 3.9 & 2.4 & 1.7 & 1.3 & 0.9 & 0.9 & 0.7 & 0.6 & 0.5 & 0.5 & 0.5 & 0.6 \\
\hline \multicolumn{1}{|c|}{ Totals } & 33.6 & 36.7 & 36.0 & 39.9 & 39.6 & 44.3 & 45.2 & 45.1 & 41.1 & 42.7 & 42.2 & 42.7 & 43.4 & 41.6 & 43.0 \\
\hline
\end{tabular}

Notes: i) percentages in relation to GDP; ii) the maturities of most federal securities are defined by the Ministry of Finance (MF); iii) bonds with fixed rates have their effective rates determined at the time of sale, which takes place at a price discounted from the face value. The law that establishes the characteristics of these bonds does not explain who is responsible for defining the sale prices, but as the issues take place either directly or in a public offer, it is presumed that the decision about sale price is the responsibility of the MF.

Source: Author's calculations from BCB.

Figure 3 demonstrates the scope of the federal debt bonds - whose issue is guided by the previously cited law - in relation to the size of the Brazilian economy. It presents evidence about the concentration of power in the decisions that have direct influence on the execution of the state budget. In 2000, the public debt securities whose interest rates were set by the BCB amounted to 21.9 percent of GDP; in 2014 this portion dropped to 8.3. Meanwhile, the Ministry of Finance (MF) was responsible for setting the interest rates for an amount of public debt equivalent to 11.7 percent of GDP in 2000 and to 34.7 percent in 2014 . Fundamentally, decisions about interest have been taken virtually solely by two agencies of the economic apparatus of the Brazilian state. The BCB and the MF combined were responsible for establishing the interest rates for a public debt that amounted to 33.6 percent of GDP in 2000, 43 percent in 2014, and an average of 41.1 percent for the 2000-2014 period. In the case of the $\mathrm{BCB}$, we have seen that a considerable portion of the expenses with interest on the debt is based on central bank's decisions about the Selic rate, which in addition to serving monetary policy, indexes a significant portion of the Brazilian public debt bonds. In 2014, nearly one-fifth of domestic federal securities were remunerated with a basis on 
this rate; from 2000 to 2014, an annual average of about forty percent of these bonds yielded returns based on the Selic rate.

\section{Expectations and monetary inductions}

The attempt to universalize certain orientations issued by the ruling classes also involves legitimacy. This legitimacy can be conferred, for example, by science, which, according to Gorz (2005), has always been intimately linked to capital. The classic works of sociology have recognized that this connection is essential to capitalist development. Both Marx and Weber perceived that this development would not have taken place with the intensity observed without the association between production and modern science. But it is not only at the level of productive infrastructure that this is revealed. Science also has a fundamental role at what Marx called the superstructural level.

What we see today is not only a science that contributes to technology (Weber, [1919] 1982) and science and technology giving power of expansion to capital (Marx, [1890] 1990); we also see science establishing truths that it reveals in clear ideological forms. For this reason Aronowitz (2000) affirms that economists, sociologists and political scientists are, with few exceptions, intellectual servants of power and technicians of social control to the degree to which they give scientific legitimacy to policies. They can do so because theories serve in various ways to provide ideological justification to authority, because research for bureaucratic purposes makes authority more effective and efficient by providing it with information (Wright Mills, [1959] 2000).

In the case of economics, there are theories that are nothing more than rationalizations for the political interests of classes and antagonistic groups (Przeworski, 1985). Recent evidence of this is the disbelief that fell on the hypothesis of efficient self-regulated markets and the political prescriptions derived from it that resulted in the global financial crisis that erupted in 2008 (Wade, 2008). Durkheim ([1895] 2001) had once indicated that so-called economic laws constitute nothing more than maxims for action, disguised practical precepts, and it was precisely the known law of supply and demand that he used as an example. For him, it was never effectively established that economic relations are processed according to the law of supply and demand. What happened, he affirmed, was nothing more than demonstrating that individuals would act in this way if they had a clear understanding of their interests and that any alternative form of action could be harmful to them.

For Callon (2007, p. 322),

economics - and this is where it derives its strength - is a constructed, logical discourse based on a number of irrefutable hypotheses. As a 
discourse it can change into a system of beliefs that infiltrate agents' minds and colonize them. For example, neoclassic theory is based on the idea that agents are self-interested. If I believe this statement and if this belief is shared by the other agents, and I believe that they believe it, then what was simply an assumption turns into a reality. Everyone ends up aligning himself or herself to the model and everyone's expectations are fulfilled by everyone else's behaviors. To predict economic agents' behaviors, an economic theory does not have to be true; it simply needs to be believed by everyone.

We thus have the so-called performativity of economics. In sum, this idea calls attention to the fact that economic models not only represent economic phenomena, but also create them (preda, 2007). The use of factors based on economics influences economic events, such as making them more probable than the very representation proposed in the scientific description (Mackenzie, 2007).

Callon clarifies that since economics and economic practice are not totally distinct worlds, the former does not have a monopoly of performativity, thus it is also exercised by the economic practioners, including the economic agents and the market professionals. In this sense, for instance, when the BCB listens to economists from the financial market - and this is what central banks do in countries that adopt inflation targeting - to assist in the formation of their convictions, it is reasonable to deduce that the $\mathrm{BCB}$ 's decisions are influenced by a peculiar type of pressure, that is the opinions of the economists consulted. This is manifest in the decision-making process described by Copom itself, whose meeting minutes mention the consideration of the expectations of the financial markets when fixing interest rates.

Figure 4

Expected and set Selic rates, November 2001 to December 2014

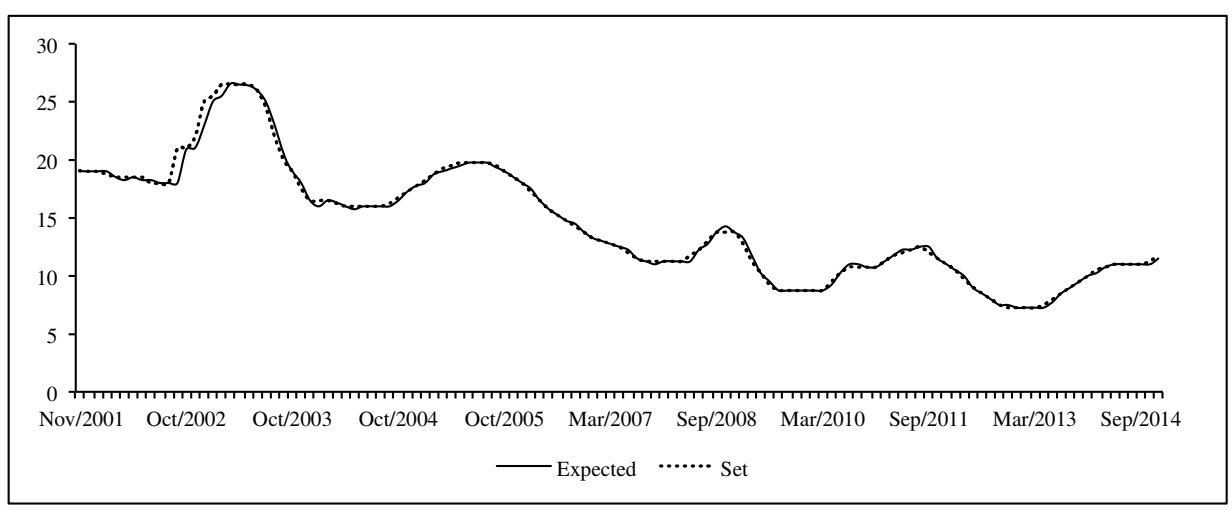

Notes: i) percent scale; ii) annual nominal rates; iii) the line "Expected" is drawn from the median of the forecasts for the target for the Selic rate during the period between the date it is set and the immediately preceding meeting of Copom that set the rate in force until then.

Source: Author's calculations from BCB. 
Considering the period from November 2001, which is when the BCB began to report the Selic rate forecasted by the organizations researched, until December 2014, there is a significant correlation between what had been expected and what effectively was established. Figure 4 presents the comparative evolution between rates expected by the financial analysts consulted by the BCB and those effectively set by Copom, whose correlation is about 0.997 .

Only from late 2002 until early 2003 did the two lines separate in a relatively significant manner throughout the entire series. These differences between the interest rates expected by the organizations consulted and those effectively set by Copom occurred during the phase between the election of President Luiz Inácio Lula da Silva and the inauguration of his government - here one must recall the traditional anti-creditor rhetoric of Lula's Worker's Party. Initially, the economy was marked by the instability of the electoral period, which eventually stabilized as the new government gave concrete signs that it would maintain the basic monetary policy of the previous government. One of these signs was the continued increase in the basic interest rates initiated in October 2002 and maintained for nearly one year at levels higher than the rate of September 2002 (see Figure 1).

On this point, it should be clarified that I am not affirming that forecasts selected by the BCB from the financial sector and other capitalists serve as a type of self-fulfilled prophecy. I am highlighting the tendency for Copom's decisions about interest rates to converge with the forecasts of those who, seeking protection for their financial investments, make subtle pressure so that the antidote to inflation - the raising of interest rates - effectively keeps both inflation and the profitability of money-capital at satisfactory levels. This indicates the sharing of ideas and beliefs between members of the state apparatus, in this case represented by Copom, and the private financial sector, represented here by a category of intellectuals - in the same sense that Gramsci ([1932] 2004) understood the "intellectuals of industry" - formed by the economists at financial institutions consulted by the BCB.

It is not at all surprising that these intellectuals present their estimates considering the context in which they are inserted and the class interests that they represent. After all, this is what those who act under the logic of capital do. Nevertheless, to all the inequalities already existing under capitalism, this one is added to give voice to a social segment - the finance - at the same time that voice is denied to others - e.g., workers or those depending on welfare policies - to defend what they think or desire, even if everyone experiences the impacts of the decisions based on these consultations. If statistics and tools used to describe a reality affect the very reality that they supposedly describe (Didier, 2007), why 
is their production restricted to influence from the fractions of class with obvious interest in the object described? There is a class component here.

It would be extremely difficult to empirically test the hypothesis that such economists issue opinions based on certain particular interests. This would depend, for example, on the improbable testimony of those who take part in processes of this type. But the hypothesis is verisimilar if it is correct to suppose that actors make their decisions in accord with the convictions forged in the context in which they construct their careers and their lives and where they share ideas with their peers. If this occurs with bureaucrats in the state economic apparatus, who, according to Stiglitz (2002), see the world through the eyes of the financial community, it is reasonable to deduce that something similar occurs among actors directly linked to finance. The contrary would be to suppose that there are social segments whose members have the exclusive privilege to analyze a certain reality with sufficient knowledge, objectivity and impartiality to make them deserving of the general confidence to say what is universal and what is correct or not.

It is important to clarify that my argument is not that finance deliberately raises its expectation of inflation seeking an automatic rise in interest rates. We recall the above quote in which Callon (2007, p. 322) says that "to predict economic agents' behaviors, an economic theory does not have to be true; it simply needs to be believed by everyone." The adverb "simply" obscures the relevance of the legitimacy that a theory - or a forecast - must have to be considered valid and accepted as a guide for action. Such theory cannot lack a significant connection with reality, even if this reality materializes with the contribution of that theory. The farther a theory is from that which is considered to be real, the more difficult it is to be trusted. Forecasts are constructed through a dialectic in which social actors share beliefs about a future that in reality they contribute to make more probable. For this reason, it is reasonable to believe that, even if it is far from being a simple induction, a discourse is tempered to some degree by the desire of the person who issues it. As Foucault ([1971] 2004, p. 10) teaches,

as much as discourse appears to be something of little importance, the interdictions that affect it rapidly reveal its connection with desire and power. There is nothing shocking in this, given that discourse - as psychoanalysis has shown - is not simply that which manifests (or hides) desire; it is also that which is the object of desire; it is seen that - history does not cease to teach us this - that discourse is not simply that which translates the struggles or the systems of domination, but that by which, through which one struggles, the power that we seek to grasp. 
Even if it seems slightly inappropriate to turn to one who thought of the microphysics of power (Foucault, 1979) and who thus does not define power as a question of class, it is interesting to recognize that the steering of the economy can involve favors to a class that are either greater or lesser, the lesser or greater were the opportunities for debate about the decisions. As Foucault ([1971] 2004) also observed, it is not any one who can speak of any thing. The economy today is perhaps the greatest example of a theme that reaches everyone, but which is debated by relatively few with an effective capacity to influence it.

\section{Conclusion: economic democracy and democratic socialism}

I have pointed to substantive and procedural contradictions that make capitalism an economic system that makes a genuinely democratic political system unviable. On the other hand, capitalism - at least the actually existent one - and democracy are not discrete categories. That is, current society cannot be characterized as purely capitalist or purely not democratic. Both categories are more useful if considered to be variables, that is, as social relations permeated by gradations of democracy and capitalism. This directs our analysis to the need to understand reality considering its transformation. The advantage of this strategy is the ability to envision a route beyond capitalism without losing sight that one must begin from capitalism to be able to abandon it.

Necessary for the realization of this possibility, even if it is not sufficient, would be the opening of routes to the democratization of the economy. This would involve a dialectic that would occupy itself in attacking the phenomena previously indicated to be structural antidemocratic characteristics of capitalism: economic inequality and the lack of participation and social control over economic decisions. Both are connected and reproduce mutually, thus, modifications in one would tend to influence the other. The increase (decrease) of economic inequality would cause greater (lesser) concentration of political power, and consequently less (more) economic and political democracy. This dialectic leaves the door half open to a different political-economic order: democratic socialism.

Democracy is a socialist principle and if the term democracy means subordination of state power to social power, the term socialism means subordination of economic power to this same social power (Wright, 2006). Thus, by democratic socialism I refer to a system in which the means of production are collectively controlled, investments are collectively defined and the fruits of these decisions collectively shared. Democratic economic planning, democracy in the workplace and the community's access to means of production are imperative for a configuration like this (Bowles; Gintis, 1986). Planning, Bowles and Gintis add, refers to the socially controlled determination of the general lines of the economic 
structure and evolution by means of collective deliberation and control over investment decisions. It thus involves, in the words of Swanson (2008), politicizing the economy, which means expanding democratic political control over economic relations, placing under public review and deliberation, in opposition to private and elitist control, the discourses and practices that, nevertheless, have collective consequences.

This observation remains valid because of what we saw about the role of the capitalist state, in which the political decisions concerning the economic apparatus are currently deeply guided by financial logic. Perhaps tomorrow there will be a different logic, but this will depend on the class fraction that is hegemonic in the accumulation process, although the state will always be capitalist while the mode of production is capitalist. Nevertheless, this does not lead us to conclude that a democratizing alternative involves denying the importance of the state in this process, advocating for example, the MarxistLeninist solution synthesized in the need to dismantle the state (Lenin, [1917] 2007).

It is thus coherent to substitute the Marxist-Leninist idea about the need to smash the state machinery by the need to smash this state machinery, recognizing that economic democracy requires that another state be constructed in the place of the capitalist state. As the latter is required by a capitalist economy, a socialist economy requires a socialist state, which has the function of providing civil society with the institutions - rules, mechanisms of coordination - without which social control over the economy and the state itself would be impossible (Wright, 2006). Democratic socialism involves the preservation of the institutions of representative democracy, although combined with direct, non-elitist and selfadministered democracy, under the threat that simple reforms in the state apparatus that are left up to this apparatus become converted into authoritarian statism. As Poulantzas (1978, p. 87) says, "socialism will be democratic or it will not be at all."

\section{References}

AMIN, S. Economia de mercado ou capitalismo financeiro oligopólico. Margem Esquerda, n. 12, p. 62-73, 2008.

ARENDT, H. Crises da república. 2. ed. São Paulo: Perspectiva, [1972] 2006.

ARONOWITZ, S. The knowledge factory: dismantling the corporate university and creating true higher learning. Boston: Beacon, 2000.

BIN, D. The class character of macroeconomic policies in Brazil of the real. Critical Sociology, v. 40, n. 3, p. 431-449, 2014. 
BIN, D. Fiscal superstructure and the deepening of labour exploitation. Capital \& Class, v. 39, n. 2, p. 221-241, 2015.

BLOCK, F.; EVANS, P. The state and the economy. In: SMELSER, N. J.; SWEDBERG, R. The handbook of economic sociology. 2. ed. Princeton: Princeton University Press, 2005. p. 505-526.

BOURDIEU, P. Razões práticas: sobre a teoria da ação. 11. ed. São Paulo: Papirus, [1994] 2011.

Le mystère du ministère: des volontés particulières à la "volonté générale". Actes de la Recherche en Science Sociales, v. 140, n. 1, p. 7-11, 2001.

BOWLES, S.; GINTIS, H. Democracy and capitalism: property, community, and the contradictions of modern social thought. New York: Basic Books, 1986.

CALLON, M. What does it mean to say that economics is performative? In: MACKENZIE, D.; MUNIESA, F.; SIU, L. Do economists make markets?: on the performativity of economics. Princeton: Princeton University Press, 2007. p. 311357.

CHESNAIS, F. Introdução geral. In: CHESNAIS, F. A mundialização financeira: gênese, custos e riscos. São Paulo: Xamã, 1998. p. 11-33.

COHEN, J.; ROGERS, J. On democracy: toward a transformation of American society. New York: Penguin, 1983.

COSTILLA, L. F. O. The reconstitution of power and democracy in the age of capital globalization. Latin American Perspectives, v. 27, n. 1, p. 82-104, 2000.

DIDIER, E. Do statistics "perform" the economy? In: MACKENZIE, D.; MUNIESA, F.; SIU, L. Do economists make markets?: on the performativity of economics. Princeton: Princeton University Press, 2007. p. 276-310.

DINIZ, E. Globalização, reformas econômicas e elites empresariais: Brasil anos 1990. 2. ed. Rio de Janeiro: Editora FGV, 2004.

DURKHEIM, É. As regras do método sociológico. 16. ed. São Paulo: Companhia Editora Nacional, [1895] 2001.

EVANS, P. Is an alternative globalization possible? Politics \& Society, v. 36, n. 2, p. 271-305, 2008.

FIGUEIREDO, A. C.; LIMONGI, F. Constitutional change, legislative performance and institutional consolidation. Revista Brasileira de Ciências Sociais, v. special issue, n. 1, p. 73-94, 2000.

FOUCAULT, M. A ordem do discurso: aula inaugural no Collège de France pronunciada em 2 de dezembro de 1970. 10. ed. São Paulo: Loyola, [1971] 2004. 
FOUCAULT, M. Microfísica do poder. 19. ed. Rio de Janeiro: Graal, 1979.

GORZ, A. O imaterial: conhecimento, valor e capital. São Paulo: Annablume, 2005.

GRAMSCI, A. Cadernos do cárcere. Rio de Janeiro: Civilização Brasileira, [1932] 2004. v. 2.

HARVEY, D. A brief history of neoliberalism. New York: Oxford University Press, 2005.

HOBSBAWM, E. The age of extremes: a history of the world, 1914-1991. New York: Vintage, 1996.

IANNI, O. Estado e capitalismo. 2. ed. São Paulo: Brasiliense, [1989] 2004.

JESSOP, B. The 'return' of the national state in the current crisis of the world market. Capital \& Class, v. 34, n. 1, p. 38-43, 2010.

LENIN, V. I. O estado e a revolução: o que ensina o marxismo sobre o estado e o papel do proletariado na revolução. São Paulo: Expressão Popular, [1917] 2007.

LEVINE, A. Democratic corporatism and/versus socialism. In: COHEN, J.; ROGERS, J. Associations and democracy. London: Verso, 1995. p. 157-166.

MACKENZIE, D. Is economics performative? Option theory and the construction of derivatives markets. In: MACKENZIE, D.; MUNIESA, F.; SIU, L. Do economists make markets?: on the performativity of economics. Princeton: Princeton University Press, 2007. p. 54-86.

MARX, K. Capital: a critique of political economy. London: Penguin, [1890] 1990. v. 1.

MINELLA, A. C. Maiores bancos privados no Brasil: um perfil econômico e sociopolítico. Sociologias, v. 18, p. 100-125, 2007.

OFFE, C. Capitalism by democratic design?: democratic theory facing the triple transition in East Central Europe. Social Research, v. 71, n. 3, p. 501-528, [1991] 2004.

Structural problems of the capitalist state: class rule and the political system. On the selectiveness of political institutions. In: VON BEYME, K. German political studies. London: Sage, 1974. v. 1, p. 31-57.

The theory of the capitalist state and the problem of policy formation.

In: LINDBERG, L. N., et al. Stress and contradiction in modern capitalism: public policy and the theory of the state. Lexington: Lexington Books, 1975. p. 125-144. 
OFFE, C. Political liberalism, group rights, and the politics of fear and trust. Studies in East European Thought, v. 53, n. 3, p. 167-182, 2001.

POULANTZAS, N. O Estado, o poder, o socialismo. 4. ed. São Paulo: Paz e Terra, [1978] 2000.

Towards a democratic socialism. New Left Review, n. I/109, p. 75-87,

1978.

PREDA, A. The sociological approach to financial markets. Journal of Economic Surveys, v. 21, n. 3, p. 506-533, 2007.

PRZEWORSKI, A. Capitalism and social democracy. Cambridge: Cambridge University Press, 1985.

p. 45-59, 1992.

. The neoliberal fallacy. Journal of Democracy, v. 3, n. 3,

ROUSSEAU, J.-J. Do contrato social. Rio de Janeiro: Nova Cultural, [1757] 2005. v. 1. (Os pensadores).

SAES, D. República do capital: capitalismo e processo político no Brasil. São Paulo: Boitempo, 2001.

STIGLITZ, J. E. Globalization and its discontents. London: Penguin, 2002.

SWANSON, J. Economic common sense and the depoliticization of the economic. Political Research Quarterly, v. 61, n. 1, p. 56-67, 2008.

WADE, R. Financial regime change? New Left Review, n. 53, p. 5-21, 2008.

WEBER, M. A política como vocação; A ciência como vocação. In: GERTH, H. H.; WRIGHT MILLS, C. Max Weber: ensaios de sociologia. 5. ed. Rio de Janeiro: LTC, [1919] 1982. p. 97-183.

Economía y sociedad: esbozo de sociología comprensiva. México:

FCE, [1922] 1964.

WEFFORT, F. C. The future of socialism. Journal of Democracy, v. 3, n. 3, p. 90-99, 1992.

WOOD, E. M. The separation of the economic and the political in capitalism. New Left Review, n. I/127, p. 66-95, 1981.

WRIGHT MILLS, C. A elite do poder. 4. ed. Rio de Janeiro: Zahar, [1956] 1981. The sociological imagination. New York: Oxford University Press, [1959] 2000.

WRIGHT, E. O. Political power, democracy, and coupon socialism. Politics \& Society, v. 22, n. 4, p. 535-548, 1994. 
WRIGHT, E. O. The debate on classes. London: Verso, 1998.

Basic income as a socialist project. Rutgers Journal of Law \& Urban Policy, v. 2, n. 1, p. 196-203, 2005.

Compass points: towards a socialist alternative. New Left Review, n. 41, p. 93-124, 2006.

ŽIŽEK, S. A utopia liberal. Margem Esquerda, n. 12, p. 43-61, 2008. 